\title{
Pengaruh Perubahan Strategi Pemasaran, Kepemimpinan Transfomasional dan Organsiasi Pembelajar terhadap Kinerja Perbankan Syariah Di DKI Jakarta
}

\author{
Muhammad Richo Rianto \\ Fakultas Ekonomi dan Bisnis, Universitas Bhayangkara Jakarta Raya \\ Email korespondensi: mrrianto@dsn.ubharajaya.ac.id
}

\begin{abstract}
This study aims to know influence marketing strategic change, transformational leadership and organization learning on performance of Indonesian Islamic. This study uses quantitative research with a purposive sampling technique with a population of 14 Indonesian islamic banks. The targeted unit of analysis is the Islamic banks manager. There were 100 questionnaires returned and 3 of them did not meet the requirements, so only 97 were used in this study. This study uses SmartPLS 3 to test the hypothesis. Findings - This research shows that strategic change, transformational leadership and organization learning affect on firm performance. Islamic banks managers must be able to identify the importance of change for the company, because of the big risks. Supporting leadership skills and organization learning in companies makes Islamic banking better competitive. Similar research is usually carried out in manufacturing and service companies and is carried out in developed countries (Europe, America and Africa). The focus of this research is the development of strategic change supported by transformational leadership and organization learning on performance. This research was also conducted for the first time in Asia with the object of Islamic banks in Jakarta Indonesia.
\end{abstract}

Keyword: strategic change, transformational leadership, organization learning, firm performance, Islamic Banks

Saran sitasi: Rianto, M. R. (2021). Pengaruh Perubahan Strategi Pemasaran, Kepemimpinan Transfomasional dan Organsiasi Pembelajar terhadap Kinerja Perbankan Syariah Di DKI Jakarta. Jurnal Ilmiah Ekonomi Islam, 7(02), 1084-1090. doi: http://dx.doi.org/10.29040/jiei.v7i2.2590

\section{DOI: http://dx.doi.org/10.29040/jiei.v7i2.2590}

\section{PENDAHULUAN}

Perbankan Syariah merupakan salah satu kompetitor industri jasa keuangan yang menjadi perhitungan saat ini. Pertumbuhan industri syariah dewasa ini menjadikan pola keuangan syariah ikut diminati. Mayoritas penduduk $87,17 \%$ yang beragama Islam menjadikan perbankan syariah memiliki potensi yang lebih baik di masa yang akan datang. (otoritas jasa keuangan, 2019) mencatat bahwa industri perbankan syariah bertumbuh dan berkembang dengan pesat, dimana pada tahun 2007 Indonesia hanya memiliki 3 perbankan syariah dan hingga tahun 2019 Indonesia memiliki 14 Bank Umum Syariah (BUS), 20 Unit Usaha Syariah (UUS) dan 165 Bank Pembiayaan Rakyat Syariah (BPRS). Berdasarkan (otoritas jasa keuangan, 2019) dalam tiga tahun terakhir 2017-2019 pertumbuhan perbankan syariah mengalami perubahan yang signifikan. Perbankan syariah mengalami trend kinerja positif selama 3 tahun terakhir dengan peningkatan jumlah total aset 47 triliun pada periode 2017-2018 dan 9 triliun pada 2018-2019. Begitu juga pada sektor pembiayaan pada perbankan syariah naik sebesar 36 triliun pada periode 2017-2018 dan 14 triliun pada periode 2018-2019. Hal yang sama juga terjadi pada sektor dana pihak ketiga (DPK) yang tumbuh secara signifikan dari tahun ke tahun. Pertumbuhan perbankan syariah yang signifikan juga didukung oleh jaringan perbankan syariah yang strategis terutama di DKI Jakarta.

Jakarta merupakan episentrum dari pertumbuhan ekonomi di Indonesia. Penduduk yang multikultur dengan keanekaragaman yang tinggi menjadikan Jakarta sebagai pusat perekonomian Indonesia. Sebagai pusat perekonomian Indonesia membuat banyak investor dan perusahaan menjadikan Jakarta sebagai target pasar yang strategis. Perbankan syariah merupakan salah satu dari banyak bisnis yang menjadikan Jakarta sebagai target pasar dengan 252 


\section{Jurnal Ilmiah Ekonomi Islam, 7(02), 2021, 1085}

cabang yang tersebar diwilayah DKI Jakarta di bawah Jawa Barat yang luas wilayahnya lebih besar. Jakarta sebagai episentrum perekonomian membuat industri perbankan syariah harus menghadapi kompetisi yang ketat. Perbankan konvensional dan perusahaan financial teknologi (FinTech) menjadi kompetitor yang saat ini sebagai rival kuat di era industri 4.0. Namun ditengah kompetisi yang ketat dalam perkembangannya perbankan syariah membuahkan hasil yang sangat memuaskan dengan meningkatnya market share dari 5\% menjadi 6,1\% . Berdasarkan (otoritas jasa keuangan, 2019) market share perbankan syariah tumbuh dari 5\% hingga 6,01\% pada oktober 2019. Pertumbuhan tersebut didukung oleh 14 Bank Umum Syariah (BUS), 20 Unit Usaha Syariah (UUS) dan 165 Bank Pembiayaan Rakyat Syariah (BPRS).

Perubahan strategi menjadi penting karena merupakan sarana yang digunakan perusahaan untuk dapat bertahan dari pesaing dan perubahan lingkungan yang merupakan ancaman bagi kinerja perusahaan (Mohammad, 2019). Oleh karena itu perusahaan harus mampu belajar untuk memulai perubahan strategi yang sesuai dengan lingkungan di mana perusahaan beroperasi untuk memperoleh peningkatan kinerja dan keunggulan kompetitif dibandingkan pesaing (Thoumrungroje, 2015) (Pangarkar, 2015).

Beberapa literatur yang meneliti mengenai perubahan strategi telah banyak dilakukan oleh peneliti dan researcher sehingga memberikan peluang untuk dapat menemukan pengembangan baru (Clarke \& Buchanan, 2010) (Kraatz \& Zajac, 2001), (Chaiporn Vithessonthi and Amonrat Thoumrungroje, 2011), (Wu et al., 2011), (Okonda et al., 2015) (Mohammad, 2019). Beberapa penelitian mengenai perubahan strategi pemasaran menghasilkan kesimpulan yang tidak konsisten. Penelitian (Barker,et al 1997), (Bergh \& Lim, 2008), (Zunigavicente et al., 2006) mendapatkan hasil bahwa perubahan strategi memiliki pengaruh positif terhadap kelangsungan hidup perusahaan perbankan di Spanyol. Namun dalam penelitian (Naranjo-Gil et al., 2008) menghasilkan bahwa perubahan strategi berpengaruh terhadap kinerja organisasi dan berdampak negatif bagi kelangsungan perusahaan.

Dinamika bisnis yang selalu berubah setiap saat menjadikan perusahaan masih terus mencari faktor yang dapat meningkatkan kinerja perusahaan agar dapat bertahan pada persaingan(Octavia \& Devie, 2015). Kepemimpinan merupakan bagian penting dalam proses bisnis karena keberhasilan perusahaan ditentukan oleh pemimpin. Gaya kepemimpinan yang baik cenderung memberikan dampak yang positif bagi organisasi. Banyak literatur yang membahas pengaruh kepemimpinan terhadap kinerja organisasi. Kepemimpinan dalam banyak literatur diteliti dalam dua dimensi yaitu kepemimpinan transaksional dan kepemimpinan transformasional. Kepemimpinan dalam penelitian ini fokus kepada kepemimpinan transformasional. Beberapa literatur menjelaskan bahwa dengan adanya seorang pemimpin yang memiliki kepemimpinan transformasional dapat mempengaruhi kinerja perusahaan yang lebih baik dari sebelumnya (Choudhary et al., 2013; GarcíaMorales et al., 2008; Octavia \& Devie, 2015).

Organisasi pembelajar merupakan pendekatan yang efektif dan efisien untuk menjawab tantangan bisnis dan memungkinkan perusahaan dapat beradaptasi secara fleksibel dalam pertumbuhan bisnis yang cepat(Mohammad, 2019). Strategi perusahaan memiliki pengaruh dengan kinerja perusahaan yang di mediasi oleh organisasi pembelajar. Hal ini terjadi karena dengan organisasi pembelajar perusahaan dapat mempertahankan keunggulan kompetitif dalam lingkungan yang dinamis dan berdampak pada peningkatan kinerja perusahaan (Vithessonthi \& Thoumrungroje, 2011), (Thoumrungroje, 2015) (Mohammad, 2019). Penelitian ini berbeda dengan penelitian lainnya yang sudah banyak dilakukan. Penelitian ini fokus pada perubahan strategi pemasaran yang konsepnya dikembangkan oleh (Barbara Stöttinger Shaoming Zou, 2015; Chaiporn Vithessonthi and Amonrat Thoumrungroje, 2011) dan pertama kali diterapkan oleh (Mohammad, 2019) pada perbankan di Nigeria. Penelitian ini melanjutkan penelitian (Mohammad, 2019) yang menambahkan pentingnya organisasi pmbelejar dan kepemimpinan transformasional. Penelitian ini juga berbeda pada banyak penelitian sejenis karena objek penelitian dilakukan pada perbankan syariah yang berada di DKI Jakarta yang merupakan episentrum perekonomian Indonesia serta dengan negara berpenduduk mayoritas beragama Islam.

\section{METODE PENELITIAN}

Penelitian ini merupakan penelitian kuantitatif dengan menggunakan metode wawancara menggunakan instrument berupa pertanyaan Penelitian ini menggunakan kuesioner untuk mengumpulkan data dalam penelitian untuk dapat di 


\section{Jurnal Ilmiah Ekonomi Islam, 7(02), 2021, 1086}

gunakan dalam menjelaskan variabel yang di maksud. SmartPls 3.0 di gunakan untuk mengetahui tingkat validitas dalam penelitian ini. Menurut (Ghozali \& Latan, 2015) validitas adalah sejauh mana hasil penelitian (1) secara akurat mewakili data yang dikumpulkan (valititas internal) dan (2) dapat di generalisasi atau ditransfer pada konteks lain (validitas eksternal). Pengujian validitas bertujuan untuk mengetahui apakah item pernyataan yang di gunakan dalam penelitian dapat mengukur variabel penelitian secara tepat. Pengujian validitas dilakukan dengan melihat content validity dan construct validity. Content validity merupakan sejauh mana pengukuran instrument dapat mewakili seluruh karakteristik variabel. Content validity bersifat judgmental. Sampel pada penelitian ini menggunakan perbankan syariah di Jakarta - Indonesia sebagai unit analisis dengan teknik purposive sampling di mana pengambilan sampel berdasarkan kriteria tertentu. Berdasarkan hasil penelusuran penelitian ini hanya memilih perbankan syariah yang memiliki cabang lebih dari 100 cabang, total aset sebanyak 30 triliun dan berada di wilayah DKI Jakarta. Responden dalam penelitian ini adalah manajer dan supervisor/officer pada perbankan syariah. Berdasarkan hasil kreteria yang ditetapkan terdapat 4 perbankan syariah yang memenuhi persyaratan dimana sebanyak 100 responden yang menjawab kuesioner dan 3 diantaranya tidak memebuhi persyaratan sehingga ada sebanyak 97 responden yang dapat di gunakan dalam penelitian ini.

Perubahan strategi pemasaran dalam penelitian ini diadopsi dari penelitian Amonrat Thoumrungroje (2016). Item yang digunakan diadopsi dari penelitian (Harun Isa Mohammad 2019) sebanyak 6 item pertanyaan. Variabel Kepemimpinan transformasional dalam penelitian ini mengadopsi pernyataan dari Garcia-Morales et al (2008) dan Ifrikhar et al.,(2013) dengan menggunakan 5 item pernyataan. Variabel organisasi pembelajar mengadopsi pernyataan dari Harun Isa Mohammad (2019) yang mana telah di modifikasi dari penelitian sebelumnya (Sinkula et al., 1997). Organisasi pembelajar dalam penelitian ini memiliki 7 item pernyataan. Variabel kinerja perusahaan merupakan variabel dependen dalam penelitian ini diukur dengan mengadopsi pernyataan dari Harun Isa Mohammad (2019) dengan 7 item pernyataan. Penelitian ini menggunakan kuesioner dengan skala likert $1-5$ dimana 1 = sangat tidak setuju, $2=$ tidak setuju, $3=$ netral, $4=$ Setuju dan $5=$ Sangat Setuju.

\section{HASIL DAN PEMBAHASAN}

\subsection{Hasil penelitian}

\section{Outer Model}

Tahap awal dalam penelitian ini adalah pengujian outer model untuk menguji validitas dan reliabilitas instrument dalam penelitian.

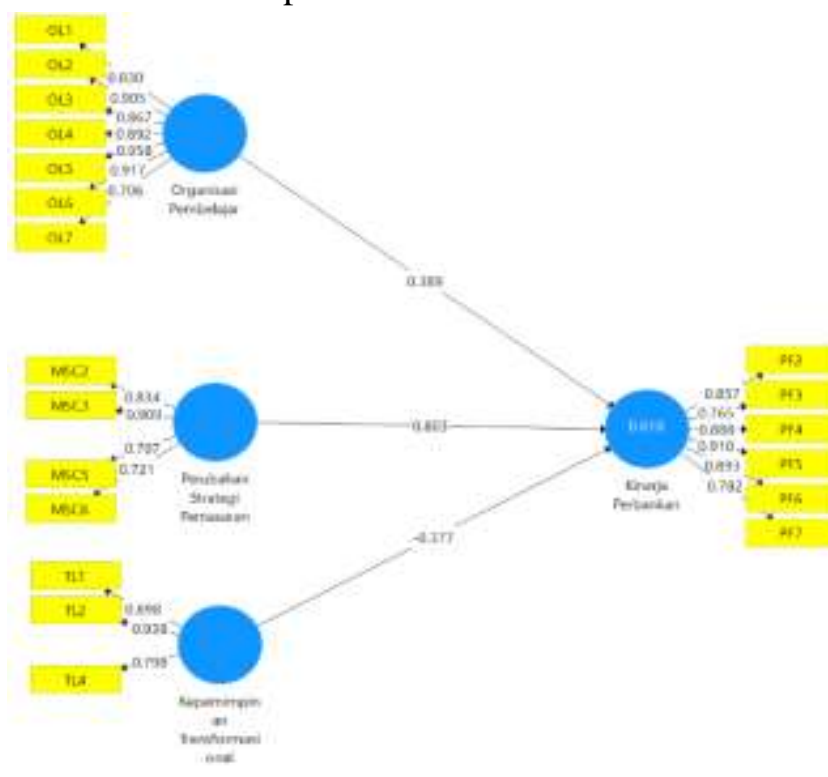

Grafik 1. Uji Outer Model Validitas

Sumber : Data diolah SmartPLS, 2021

Berdasarkan gambar 1 uji outer model validitas diatas dapat disimpulkan bahwa beberapa instrument tidak memenuhi persyaratan / tidak valid karena memiliki nilai dibawah $(<0,7)$. Convergent validity merupakan pengujian yang dilakukan untuk mengetahui pengaruh antara variabel dengan indikator. Semakin tinggi nilai loading factor maka semakin tinggi pula korelasinya dan indikator dinyatakan valid atau layak. Convergent validity di nilai berdasarkan loading factor. Untuk menilai validitas konvergen yaitu nilai loading factor berkorelasi > 0,7. (Ghozali \& Latan, 2015). Berdasarkan grafik diatas dapat disimpulkan bahwa variabel perubahan strategi pemasaran pada item 1 dan 4, variabel kepemimpinan transformasional untuk item 3 dan 5, variabel kinerja pada item 1 harus dihilangkan karena memiliki nilai dibawah $(<0,7)$.

\begin{tabular}{|c|c|c|c|c|}
\hline & Gonbacts Ngho & $\tan A$ & Composte Reiditity & 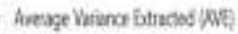 \\
\hline Kepeninpisan Trarsiamsiond & 0.854 & 0.910 & 0.911 & 0.774 \\
\hline Nireip Pertonian & 0.525 & 0.929 & 0.48 & $\Delta \pi n$ \\
\hline Orgrisasi Pembelajy & 0.54 & 2.956 & 0.556 & 0.759 \\
\hline Penbohen Striteg Pernocan & 0305 & 0.331 & Q887 & sas \\
\hline
\end{tabular}

Tabel 1. Uji Outer Model Reliabilitas

Sumber : Data yang diolah SmartPLS, 2021 


\section{Jurnal Ilmiah Ekonomi Islam, 7(02), 2021, 1087}

Berdasarkan table 1 outer model reliabilitas diatas dapat dijelaskan bahwa nilai Cronbach's alpha memiliki nilai > 0.7. Composite reliability di gunakan untuk menilai apakah indikator pada variabel penelitian reliabel atau tidak. Suatu indikator di katakan reliabel apabila nilai composite reliability tinggi. Untuk menilai reliabilitas yaitu nilai composite reliability > 0,7 (Ghozali \& Latan, 2015). Berdasarkan hasil dari table 1 diatas dapat disimpulkan variabel perubahan strategi pemasaran, kepemimpinan transformasional, organsiasi pembelajar dan kinerja memiliki nilai diatas 0,7 dan dapat dikatan reliabel serta memenuhi syarat untuk tahap berikutnya.

\section{Inner Model}

Tahapan kedua dalam penelitian ini adalah uji inner model yang digunakan untuk menjawab hipotesis dalam penelitian.

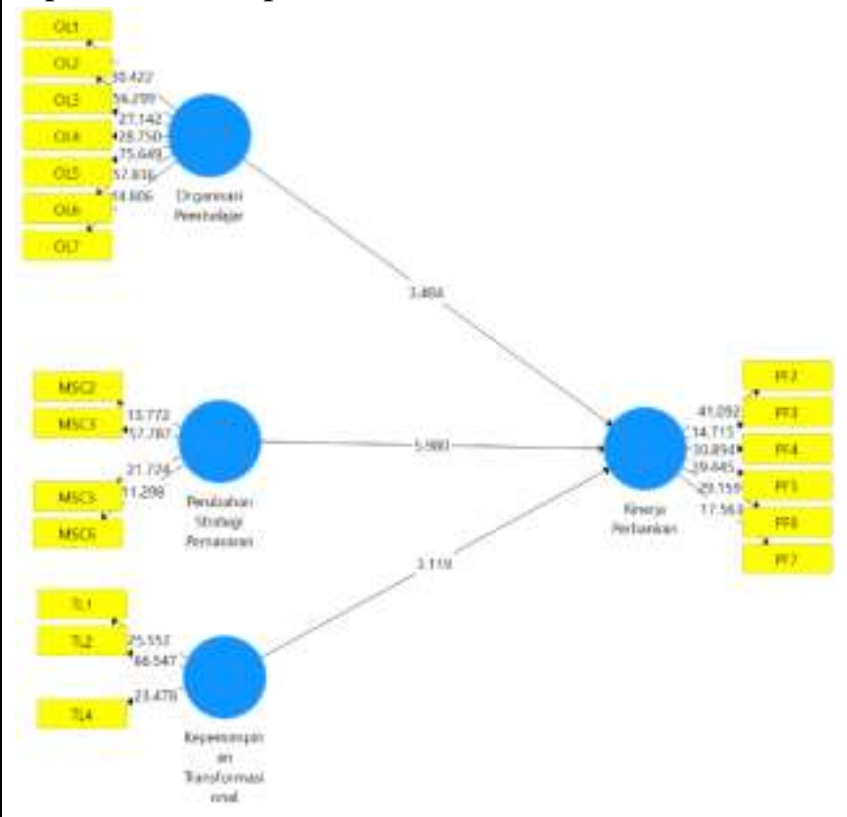

Gambar 2 Uji Inner Model

Sumber : Data dioleh Smart PLS, 2021

\begin{tabular}{|c|c|c|c|c|c|}
\hline & Originat- & Sample. & nadow. & Satistic. & $P W$ \\
\hline 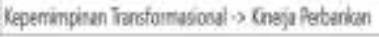 & $037 \pi$ & 0393 & 0.121 & 3.119 & 0.002 \\
\hline Orgarissi Penbeliy : & Q3399 & 0392 & Q1:12 & 3.644 & 4 \\
\hline 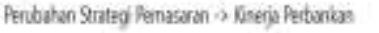 & Q983 & 0893 & $0: 134$ & 5890 & $a 0$ \\
\hline
\end{tabular}

Tabel 2 Uji Inner Model

Sumber : Data diolah SmartPLS, 2021

Berdasarkan gambar 2 dan table 2 dapat disimpulkan bahwa Perubahan strategi pemasaran berpengaruh terhadap kinerja perbankan syariah dengan nilai p-value 0,000 dimana $(0,000<0,05)$. Begitu hal nya dengan pengaruh kepemimpinan transformasional dengan nilai $\mathrm{p}$-value sebesar 0,002 dimana $(0,002<0,05)$ sehingga dapat disimpulkan terdapat pengaruh kepemimpinan transformasional terhadap kinerja perbankan syariah. Variabel organisiasi pembelajar juga memberikan hasil yang sama dengan nilai p-value sebesar 0,001 dimana $(0,001<0,05)$ sehingga dapat disimpulkan bahwa organsiasi pembelajar berpengaruh terhadap kinerja perbankan syariah.

Hasil ini juga memberikan gambaran bahwa perubahan strategi pemasaran memiliki pengaruh positif dengan nilai original sampel sebesar 0,803 yang artinya semakin banyak perubahan pemasaran yang dilakukan maka akan meningkatkan kinerja perbankan syariah. Hal yang sama ditunjukkan oleh kepemimpinan transformasional yang berkorelasi positif dengan nilai original sampel sebesar 0,377 yang artinya semakin tinggi kepemimpinan transformasional dalam perbankan syariah, maka akan meningkatkan kinerja perbankan syariah. Hal serupa pada variabel organisasi pembelajar dengan nilai original sampel sebesar 0,389 yang membuktikan bahwa semakin tinggi tingkat organsiasi pembelajar dalam perbankan syariah, maka akan meningkatkan kinerja pada perbankan syariah.

\subsection{Pembahasan}

Berdasarkan hasil temuan diatas dimana perubahan strategi pemasaran berpengaruh terhadap kinerja perbankan syariah. Hal ini sejalan dengan penelitian yang dilakukan oleh (Mohammad, 2019)(Naranjo-Gil et al., 2008) (Clarke \& Buchanan, 2010)(Barker \& Duhaime, 1997; Bergh \& Lim, 2008). Perubahan strategi merupakan cara paling strategis dalam meningkatkan kinerja perusahaan (Clarke \& Buchanan, 2010) (Kraatz \& Zajac, 2001). Hasil temuan ini semakin memperkuat perubahan strategi perubahan pemasaran menjadi cara bagi perusahaan untuk meningkatkan kinerja lebih baik(Pangarkar, 2015). Perusahaan yang melakukan perubahan senantiasa menganalisa pengaruh pengambilan keputusan dengan perubahan strategi perusahaan yang dilakukan (Mohammad, 2019). Perbedaan pandangan mengenai perubahan strategi yang harus dilakukan saat perusahaan dalam keadaan menurun (Barker \& Duhaime, 1997; Clarke \& Buchanan, 2010) atau dalam keadaan bertahan dan meningkatkan kinerja (Salavou, 2015) dengan adanya perubahan strategi bukan menjadi bagian yang penting karena kedua pandangan tersebut memiliki kesamaan bahwa strategi perubahan harus dilakukan dan digunakan 


\section{Jurnal Ilmiah Ekonomi Islam, 7(02), 2021, 1088}

untuk meningkatkan kinerja perusahaan. Perusahaan yang mengalami kemunduran dan kegagalan adalah ketika perusahaan tidak melakukan perubahan strategi pemasaran untuk meningkatkan kinerja perusahaan (Salavou, 2015).

Pengaruh positif dapat di definisikan semakin banyak perubahan strategi pemasaran yang dilakukan untuk mencapai tujuan perusahaan, maka kinerja perusahaan semakian baik. Penemuan ini semakin memperjelas bahwa perubahan strategi menjadi sumber utama dalam peningkatan kinerja perusahaan (Barbara Stöttinger Shaoming Zou, 2015). Perubahan strategi pemasaran juga menjadi jawaban dari ketidakpastian di masa yang akan datang terhadap perubahan lingkungan perusahaan (Mukherji \& Mukherji, 2016). Perubahan strategi pemasaran yang dilakukan oleh perbankan syariah adalah perubahan strategi pemasaran pada produk, misalnya pada saat pandemic covid 19 Bank Syariah Mandiri (BSM) perbankan syariah melakukan banyak perubahan perubahan untuk meningkatkan kinerja perusahaan. Perubahan ini secara otomatis akan meningkatkan kinerja perbankan syariah sehingga dimasa yang akan datang dimana perbankan syariah memiliki kemampuan untuk beradaptasi dengan cepat karena perusahaan sudah belajar dan terbiasa untuk melakukan perubahan.

Penelitian ini juga memberikan hasil adanya pengaruh kepemimpinan trasnformasional terhadap kinerja perbankan syariah. Pengaruh kepemimpinan transformasional terhadap kinerja perusahaan yang positif berarti semakin tinggi kepemimpinan transformasional dalam perusahaan maka kinerja perusahaan akan semakin meningkat dan sebaliknya Penelitian ini sejalan dengan penelitian yang dilakukan oleh (Choudhary et al., 2013) yang menyimpulkan bahwa kepemimpinan transformasional berpengaruh terhadap kinerja perusahaan. Kepemimpinan transformasional menjadikan karyawan memiliki motivasi yang lebih baik (Bass et al., 2003). Dengan motivasi yang lebih baik karyawan akan bekerja melewati batas kemampuannya sehingga kinerja perusahaan menjadi lebih baik (Prajogo, 2013). Kepemimpian transformasional yang bersumber dari idealized influence seperti karisma akan memunculkan emosi dan identifikasi karyawan yang kuat terhadap atasannya. Pemimpin yang memiliki karisma yang tinggi akan memberikan pengalaman emosi tertentu pada karyawan nya, di mana karyawan akan mematuhi dan meniru apa yang dilakukan oleh atasan nya ( role model). Sehingga semakin tinggi karisma dalam kepemimpinan transformasional maka karyawan akan mengagumi atasannya dan akan bekerja lebih baik (Prajogo, 2013). Kepemimpinan transformasional juga bersumber pada simulasi intelektual yang menjadikan karyawan memiliki cara pandang baru dalam menyelesaikan masalah sehingga karyawan merasa tertantang dan dipercaya. Hal ini dapat berdampak pada tumbuhnya kreativitas pada karyawan yang dapat meningkatkan kinerja perusahaan. (Bass et al., 2003). Begitu hal nya dengan komunikasi visi ( share vision) dan pemberian dukungan dalam kepemimpinan transformasional yang menjadikan karyawan arah dan tujuan pencapaian perusahaan serta dukungan dalam melakukan aktivitas pekerjaan yang berdampak pada peningkatan kinerja perusahaan (Bass et al., 2003; Prajogo, 2013).

Penelitian ini juga menunjukkan adanya pengaruh organsiasi pembelajar terhadap kinerja perbankan syariah. Pengaruh organisasi pembelajar terhadap kinerja yang positif berarti semakin tinggi organisasi pembelajar dalam perusahaan maka akan meningkatkan kinerja perusahaan dan sebaliknya. Penelitian ini sejalan dengan penelitian yang dilakukan oleh (Mohammad, 2019; Nafei, 2014; Octavia \& Devie, 2015; Pradana, 2014). Penerapan organisasi pembelajar dalam perusahaan menjadikan perusahaan dituntut untuk terus belajar dapat beradaptasi dengan mudah terhadap perubahan lingkungan yang dinamis. (Mohammad, 2019). Temuan ini semakin kuat menjelaskan peranan organisasi pembelajar dalam meningkatkan kinerja perusahaan. Organisasi pembelajar memiliki pengaruh terhadap peningkatan kinerja perusahaan karena organisasi pembelajar tidak hanya mendeskripsikan apa, mengapa, kapan dan bagaimana, melainkan seperti apa perusahaan bereaksi terhadap gejala gejala yang harus di hadapi oleh perusahaan untuk dapat memiliki kinerja yang lebih baik (Mohammad, 2019). Kemampuan perusahaan dalam belajar secara terus menerus merupakan keunggulan kompetitif pada persaingan yang ketat dewasa ini (Santos-Vijande et al., 2012). Organisasi pembelajar merupakan strategi utama perusahaan dalam memberikan terobosan baru untuk meningkatkan kinerja perusahaan yang memungkinkan munculnya peluang peluang baru dalam berkompetisi (Santos-Vijande et al., 2012). 


\section{KESIMPULAN}

Berdasarkan argumentasi, inkonsistensi penelitian sebelumnya dan temuan dari penelitian ini maka dapat disimpulkan bahwa perubahan strategi pemasaran berpengaruh terhadap kinerja perbankan syariah, kepemimpinan transformasional berpengaruh terhadap kinerja perbankan syariah dan organsiasi pembelajar berpengaruh terhadap kinerja perbankan syariah di DKI Jakarta. Penelitian selanjutnya dapat memberikan rekomendasi faktor lain yang mempengaruhi kinerja pada perbankan syariah. Beberapa penelitian terdahulu merekomendasikan peranan mediasi inovasi dalam peningkatan kinerja perusahaan. Beberapa literatur juga menambahkan Faktor dukungan pemerintah, dimana dukungan pemerintah merupakan bagian penting dalam peningkatan kinerja perbankan syariah baik secara internal dan eksternal.

\section{UCAPAN TERIMA KASIH}

Penulis menyadari bahwa penelitian ini masih jauh dari kata sempurna namun peneliti berharap penelitian ini dapat memberikan ilmu dan referensi baru bagi dunia Pendidikan dan Industri perbankan syariah pada umumnya. Peneliti mengucapkan terimakasih kepada pihak-pihak yang telah membantu hingga tulisan dan penelitian ini dapat diselesaikan dengan baik.

\section{REFERENSI}

Barbara Stöttinger Shaoming Zou, B. B. S. (2015). International Marketing in the Fast Changing World. International Marketing in the Fast Changing World Advances in International Marketing,

https://doi.org/10.1108/02652320010315316

Download. https://doi.org/doi:10.1108/S1474797920150000026015

Barker, V. L., \& Duhaime, I. M. (1997). Strategic change in the turnaround process: Theory and empirical evidence. Strategic Management Journal, $\quad 18(1), \quad 13-38$. https://doi.org/10.1002/(sici)1097-

0266(199701)18:1<13::aid-smj843>3.3.co;2-o

Bass, B. M., Avolio, B. J., \& Jung, D. I. (2003). Predicting Unit Performance by Assessing Transformational and Transactional Leadership. 88(2), 207-218. https://doi.org/10.1037/00219010.88.2.207
Bergh, D. D., \& Lim, E. N. (2008). LEARNING HOW TO RESTRUCTURE : ABSORPTIVE CAPACITY AND IMPROVISATIONAL VIEWS OF RESTRUCTURING ACTIONS AND PERFORMANCE. 616(December 2007), 593616. https://doi.org/10.1002/smj

Chaiporn Vithessonthi and Amonrat Thoumrungroje. (2011). Strategic change and firm performance: the moderating effect of organisational learning. https://doi.org/10.1108/15587891111152348

Choudhary, A. I., Akhtar, S. A., \& Zaheer, A. (2013). Impact of Transformational and Servant Leadership on Organizational Performance: A Comparative Analysis. Journal of Business Ethics, 116(2), 433-440. https://doi.org/10.1007/s10551-012-1470-8

Clarke, R., \& Buchanan, B. (2010). Turnaround strategies. Trustee: The Journal for Hospital Governing Boards, 63(6), 19-31. https://doi.org/10.4324/9781315738116-8

García-Morales, V. J., Lloréns-Montes, F. J., \& Verdú-Jover, A. J. (2008). The effects of transformational leadership on organizational performance through knowledge and innovation. British Journal of Management, 19(4), 299-319. https://doi.org/10.1111/j.1467-

8551.2007.00547.x

Ghozali, I., \& Latan, H. (2015). Partial Least Squares: Konsep, Teknik dan Aplikasi menggunakan Program SmartPLS 3.0. Semarang: Universitas Diponegoro.

Kraatz, M. S., \& Zajac, E. J. (2001). How Organizational Resources Affect Strategic Change and Performance in Turbulent Environments: Theory and Evidence. Organization Science, 12(5), 632-657. https://doi.org/10.1287/orsc.12.5.632.10088

Mohammad, H. I. (2019). Mediating effect of organizational learning and moderating role of environmental dynamism on the relationship between strategic change and firm performance. Journal of Strategy and Management, 12(2), 275-297. https://doi.org/10.1108/JSMA-072018-0064

Mukherji, A., \& Mukherji, J. (2016). Environmental Uncertainty and Positive Performance of Small Firms: The Roles of Key Mediators. Academy of Management Proceedings, 2016(1), 10437. https://doi.org/10.5465/ambpp.2016.10437abstra ct 
Nafei, W. (2014). The Mediating Effects of Organizational Learning on the Relationship between Knowledge Management and Organizational Performance: An Applied Study on the Egyptian Commercial Banks. International Journal of Business and Management, $\quad 9(2), \quad$ 244-261. https://doi.org/10.5539/ijbm.v9n2p244

Naranjo-Gil, D., Hartmann, F., \& Maas, V. S. (2008). Top management team heterogeneity, strategic change and operational performance. British Journal of Management, 19(3), 222-234. https://doi.org/10.1111/j.14678551.2007.00545.x

Octavia, L., \& Devie. (2015). Pengaruh Transformational Leadership Terhadap University Performance Dengan Learning Organization Dan University Culture Sebagai Variabel Intervening. Business Accounting Review, 3(1), 489-500.

Okonda, M. W., Ojera, D. P. B., \& Ochieng, D. I. O. (2015). The Moderating Effect of Firm Characteristics on the Relationship between Strategic Change and Performance of Firms in the Alcohol Industry in Kenya. IJARS International Journal of Management and Corporate Affairs, 2(3). https://doi.org/10.20908/ijarsijmca.v2i3.10784

otoritas jasa keuangan. (2019). Statistik Perbankan Syariah - Desember. Journal of Chemical Information and Modeling, 53(9), 1689-1699. https://www.ojk.go.id/id/kanal/syariah/data-danstatistik/statistik-perbankansyariah/Documents/Pages/Statistik-PerbankanSyariah---Desember-2019/SPS Desember 2019.pdf

Pangarkar, N. (2015). Performance implications of strategic changes: An integrative framework. Business Horizons. https://doi.org/10.1016/j.bushor.2015.01.003

Pradana, B. I. (2014). Peran Organizational Learning dalam Penerapan Knowledge Management untuk mencapai Organizational Effectiveness. Jurnal Ekonomi Dan Bisnis Universitas Brawijaya, October, $\quad 0-10$. https://www.researchgate.net/profile/Bayu_Prad ana2/publication/277224118_HUBUNGAN_A NTARA_KNOWLEDGE_MANAGEMENT_D AN_ORGANIZATIONAL_LEARNING_SERT A_DAMPAKNYA_PADA_ORGANIZATION AL_EFFECTIVENESS_Studi_pada_Telkom_M alang/links/59de1256a6fdccc2e0f4ee79/HUBU NGAN-AN
Prajogo, W. (2013). Pengaruh Dimensi-Dimensi Kepemimpinan Transformasional Dan Transaksional Pada Kinerja Karyawan. Modul, 25(2), 125-138.

Santos-Vijande, M. L., López-Sánchez, J. Á., \& González-Mieres, C. (2012). Organizational learning, innovation, and performance in KIBS. In Journal of Management \& Organization (Vol. 18, Issue 6). https://doi.org/10.1017/s183336720000050x

Sinkula, J. M., Baker, W. E., \& Noordewier, T. (1997). A framework for market-based organizational learning: Linking values, knowledge, and behavior. Journal of the Academy of Marketing Science, 25(4), 305-318. https://doi.org/10.1177/0092070397254003

Thoumrungroje, A. (2015). THE MODERATING ROLES OF ORGANIZATIONAL LEARNING AND STRATEGIC FLEXIBILITY ON MARKETING STRATEGIC CHANGE AND BUSINESS PERFORMANCE: EVIDENCE FROM FIRMS IN THAILAND. International Marketing in the Fast Changing World Advances in International Marketing, 26, 179-198.

Vithessonthi, C., \& Thoumrungroje, A. (2011). Strategic change and firm performance: the moderating effect of organisational learning. Journal of Asia Business Studies, 5(2), 194-210. https://doi.org/10.1108/15587891111152348

Wu, Y., Wei, Z., \& Liang, Q. (2011). Top management team diversity and strategic change: The moderating effects of pay imparity and organization slack. Journal of Organizational Change Management, 24(3), 267-281. https://doi.org/10.1108/09534811111132686 